\title{
Sociological Approaches to Qumran Sectarianism
}

\author{
Jokiranta, Jutta
}

Oxford University Press

2010

Jokiranta , J 2010 , Sociological Approaches to Qumran Sectarianism . in T H Lim \& J J Collins (eds), The Oxford Handbook of the Dead Sea Scrolls . Oxford University Press, Oxford, pp. 200-231.

http://hdl.handle.net/10138/156553

acceptedVersion

Downloaded from Helda, University of Helsinki institutional repository.

This is an electronic reprint of the original article.

This reprint may differ from the original in pagination and typographic detail.

Please cite the original version. 


\section{H A P T E R 8}

\section{SOCIOLOGICAL \\ APPROACHES TO QUMRAN SECTARIANISM}

\section{JUTTA JOKIRANTA}

Scholarly reflection on the people behind the Qumran documents has been coloured by the use of the term 'sect' from very early on, ever since the first announcement of the discovery of the scrolls was made in 1948. The term was and continues to be widely used in a loose sense, without any explicit sociological pre-understanding, almost equal to 'a (religious) group/subgroup' (yet it carries implicit sociological assumptions). However, more and more scholars have also made an effort to be sociologically informed when hypothesizing about the Qumran movement and its nature. Here I discuss the prospects of using the sociology of sectarianism in the study of the Dead Sea Scrolls. The emphasis is on sociological approaches, even though some social-psychological perspectives are also referred to.

What constitutes a 'sociological approach' to the study of antiquity in the first place is a matter under discussion. Certainly, a sociological approach assumes a

1 This chapter benefited from comments by Prof. David Chalcraft as well as the Project members of 'Explaining Early Jewish and Christian Movements: Ritual, Memory and Identity'. All the remaining shortcomings are naturally on my responsibility. 
certain link between ideas and beliefs on the one hand and social forms and material factors on the other hand, but the link is not mechanistic or deterministic. Sociology illuminates the social conditions within which human action takes place but also allows for particularities (Horrell 1996: 9-32; cf. Wilson 1973: 502). Historical investigations cannot do without theoretical assumptions of the 'social'. Moreover, historical sociology, which studies past societies, is different from contemporary sociology in that by necessity it makes use of methods other than questionnaires and fieldwork (Berquist 1995: 242).

Some scholars employing the social sciences in biblical studies distinguish social-scientific approaches from socio-historical ones, and argue that the explicit articulation of 'models' ('social-scientific') is better for avoiding anachronism (Elliott 1993; Esler 1995; on the use of 'models', see discussion by Esler 2000; Horrell 2000; and Luomanen, Pyysiäinen, and Uro 2007: 18-20). These various opinions partly arise from sociology itself. There is a difference, for example, between 'interpretative' and 'positivistic' trends, between 'imagination' and 'science,' between understanding society in terms of meaningful individual actions and analysing society as an objective entity (Chalcraft 1997: 16; Mayes 1989: 118-20, and see Mayes' helpful introduction of both 'conflict tradition' and 'structural-functionalist tradition' in sociology, identified with Max Weber and Emile Durkheim respectively).

Biblical scholars would do well to reflect on theoretical assumptions and to become more familiar with sociological theorizing, but also to cultivate a sociological way of thinking. Heuristic tools are not insignificant. It should be accepted that their benefits are not always guaranteed, nor immediately obvious. The aim of sociological approaches in biblical studies is, in the end, to 'challenge, to broaden and to reformulate the methods of historical criticism' (Horrell 1996: 30) and to understand those processes of social life that cannot be unravelled or reconstructed without the aid of sociological concepts and imagination.

\section{Two Sociological Approaches To Qumran Sectarianism}

No one agreed definition of 'sect' exists. Sociological studies on sectarianism do not provide any ready-made set of hypotheses about sects that could then be tested against the ancient material. Each sociological study on sects has attempted to answer specific questions in a particular setting. Many sociologists, perhaps Max Weber most notably, have been keen on explaining the influences of sects on the wider social and cultural environment, e.g. seeing the belief systems of sects as one important factor in, if not a cause for, changes towards modernity. In biblical 
studies, such 'classical' theorists are often referred to in passing, and biblical scholars have tended to focus on the work of more recent sociologists, Bryan Wilson in particular. Familiarity with differences between the work of sociologists and the kinds of concepts used is needed in order to establish the foundation on which biblical scholars can make informed choices between sociological approaches. In the following, two sets of questions are discussed in order to illustrate the particular frameworks characteristic of different sociologists: first, Max Weber and the formation of sectarian personality with its societal impact, and second, types of sects and lifecycles of sects, especially the work of Bryan R. Wilson, Rodney Stark, and William Sims Bainbridge and their reformulations of the 'sect' within twentieth-century societies.

\section{Type of Character and Societal Impact}

\section{Weber and Ideal Type}

Max Weber's (1864-1920) conception of 'sect' remains important because of its 'ideal typical' nature and its use as a methodological tool. Commentators explain that Weber's philosophical starting point is to be found in the view that reality is too complex to be understood in the mind in its totality; abstractions and simplifications are needed in order to comprehend it. Many of the concepts of the social sciences are neither 'individual' (describing individual events) nor 'general' (formulating universal laws) but rather 'typical': they are a 'one-sided accentuation' of those aspects that are culturally significant (Hekman 1983: 18-26; Gerhardt 2001: 236). In Weber's words (1949: 90): 'An ideal type is formed by the one-sided accentuation of one or more points of view and by the synthesis of a great many diffuse, discrete, more or less present and occasionally absent concrete individual phenomena, which are arranged according to those one-sidedly emphasized viewpoints into a unified analytical construct.' Ideal types are intentionally unreal extremes (e.g. the ideal types of 'bureaucracy', 'economist', 'Calvinist'). The characterization of the 'Calvinist ethic', for example, was derived from several pastoral and historical writings of Calvinists. It did not summarize all of the points in common in them but accentuated features that were considered of value to the topic of the inquiry, the formation of the capitalist spirit (Giddens 1971: 141-2; Kalberg 2005: 14-22). Ideal types, then, can help organize research and offer suggestions of where to look for explanations about human behaviour as well as to make the reality more comprehensible to us (Hughes, Martin, and Sharrock 1995: 133-4; Chalcraft 2007c: 206). 
Weber insisted that the ideal type is not found in any single concrete case. It cannot be proven 'wrong' by cases that do not 'fit' since it is not a comprehensive description of a single social institution or process but is rather a means towards the proposition of causal hypotheses. Ideal types are historically defined and are subject to change (Hekman 1983: 36). Weber himself studied historical cases, traditional Chinese, Indian, and ancient Israelite societies, in comparison to modern Western society, thus making theoretical concepts serve historical case studies (Hughes, Martin, and Sharrock 1995: 135-41). Ideal types are not the ends of scientific inquiry but the means to facilitate analysis of the subject to be explained (Giddens 1971: 139-44).

'Sect' and 'church' can serve both as descriptive concepts and as ideal typical concepts (Giddens 1971: 142). As a descriptive concept, sect presents a synthesis of those features that are common to certain empirical cases and are distinct from church. As an ideal typical concept, sect accentuates certain culturally significant features. What is viewed as culturally significant will change according to time and the interest of the inquiry (Bruun 2001: 156). For Weber, sect was a conceptual tool for investigating those features that influenced the rationalization of modern culture (Chalcraft 2007b). Weber sought to identify the value-orientations in a society that contributed to rational, systematic forms of conduct (in contrast to irrational, random forms). In his theory, such values were characteristic of modern societies and capitalist economy, and through their systematic, disciplined conduct Protestant sects were for their part contributing to the formation and expansion of such values. Weber's use of 'sect' was free of value judgement, and, for Weber, sects could be of many kinds (religious, 'aesthetic', even scientific-Weber mentioned Freudian circles): 'Specific, firmly articulated ideals can be brought into life in no way other than in the founding of a sect whose enthusiastic followers strive to realize them fully, and who therefore unite with one another and set themselves apart from others' (Weber 2002b: 206-7).

\section{Weber and Virtuoso Personality}

In Weber's work, the accentuated feature of a sect was a voluntary membership based on some merit or qualification. A key for Weber's understanding of sect is his idea about associational life (Vereinswesen), voluntary membership in all kinds of associations, 'from a bowling club to a political party' (Weber 2002b). The archetype of associational life was the Protestant sect but associational life could characterize a whole society-Weber identified North America as a 'sect-like society'. Associations select and cultivate their members, making them channels of change. A member has to qualify, 'to assert himself', and, once qualified, the member will be disciplined according to the group's norms. Self-monitoring becomes a habit, both because of internal competition within a sect and external 
competition between sects (Kim 2002: 196). Weber was fascinated to find that sect membership functioned as a moral certificate in American society, e.g. in obtaining loans and credit. Sect membership meant that a person had qualified, passed an examination, and 'asserted' him/herself both externally and internally. Sects developed individual personalities, virtuosos, in ways that had an impact not only on the lives of the individual members, but on society as a whole.

Virtuoso mentality combined with certain religious ideas had an influence on the formation of modern capitalism. In his The Protestant Ethic and the Spirit of Capitalism (Weber 2002a), Weber identified 'the spirit of capitalism' which was to work well, to make a profit, and to use one's time wisely. The Protestant ideal was to fulfil one's God-given task in the practical, secular life (Hughes, Martin, and Sharrock 1995: 100-1; Kalberg 2005: 24-7). The calling of Catholic monks into an other-worldly life was replaced by the inner-worldly asceticism of Protestant sects (for the development of Weber's ideas about sects, see Chalcraft 2007b). Which underlying beliefs enforce this type of character formation? For Weber, it was the predestinarian beliefs in the Calvinist tradition that were seen to have the most effect in the creation of rational, secular asceticism. According to Calvinist teaching, people's eternal fate was predestined by and known only to God. There was no external proof whether one was among those predestined for eternal life or not. This uncertainty, however, caused salvation anxiety in people's minds and a need to ascertain one's status. Such anxiety led people to carry out the spirit of capitalism in their everyday life-working hard, making wise investments, being efficient—in order to assure oneself that one's lot was among those predestined for salvation, or at least to clear away doubt.

In wider terms, 'rationalization' meant the tendency to systematically organize, plan, and conduct one's affairs - this was expressed, in particular, in the areas of science and business (Hughes, Martin, and Sharrock 1995: 96). 'Disenchantment' referred to the process by which the world became a less magical place and more governed by predictable rules (Hughes, Martin, and Sharrock 1995: 121). Although Weber saw a clear connection between the Protestant sects and the new rational, capitalist spirit, he also recognized roots of rationalization going further back in time, to ancient Israel and Greece (Hughes, Martin, and Sharrock 1995: 119-20). By rejecting magic and demanding an ethical way of everyday life, pre-exilic biblical prophets contributed to inner-worldly action. Rationalization in ancient settings was exemplified by systematization of laws, the existence of publicly verifiable norms, trained experts, and abstract rules as well as by economic 'asceticism', the idea that trustworthiness goes together with the best possible profit (Mayes 1989: 22-5). However, the post-exilic period was, in Weber's view, characterized by the decrease of this tendency, by the social segregation of the Jewish people, and the observance of concrete norms rather than abstract principles (Schluchter 1989: 165-8). 


\section{Case Study I: Weberian Character Formation in the Qumran Movement}

One central feature to be investigated in the Weberian tradition is the formation of the virtuoso personality in sects. The sociologist assumes that people strive for a sense of worth about themselves and thus look for ways to be 'heroic'. One channel to carry out values esteemed in the society is provided by sects, especially when other, perhaps more traditional channels are blocked (Chalcraft forthcoming).

In his Ancient Judaism, Weber says little about the Greek, the Hasmonean, and the Roman periods as such but includes a lengthy discussion on the Pharisees and the Essenes (note that Weber did not know the Qumran material). For Weber, the Hasidim were the forerunners of the Pharisees: the Pharisees gave the movement an order by making devotion to proper purity a rule. Gradually, the status of priests was degraded 'in favor of personal religious qualification as proven through conduct' (Weber 1952: 386). The Pharisees were an inter-local sect who lived in the same purity as priests and thus claimed equal holiness to priests. The opposition between these ritual virtuosos and the 'am ha-'aretz was intensified. Weber denies that the self-control found in the observance of purity rules had any major impact on developing ascetic ways of life similar to later Christian cases. But here Weber notes the existence of Essenism: '[The] pursuit of purity could vary in intensity. Normally it led the Pharisees to become increasingly exclusive and systematically ritualistic. This correctness as mentioned did not require separation from workaday life. But the principle could also be pushed beyond the demands of inner-worldly morality. This was the basis of Essenism which, from this point of view, was merely a radical Pharisaic sect' (Weber 1952: 406).

Even though the connection between the Pharisees and the Essenes perceived in this way is historically false, their sociological resemblance might well be significant in this period. Both Pharisees and the Essenes, as well as the Qumran movement, ${ }^{2}$ are examples of social groups that bred 'virtuosos': members who sought ways to assert themselves and who came to view the world in particular ways and themselves as disciplined and qualified, fulfilling certain norms. Asceticism is not only to be linked to systems which see the body and the soul as separate and deny the former; rather it is perfection, training, and attainment of higher goals that characterize these ascetic practices. If asceticism is understood in such a broad sense, as a means through which theological beliefs were internalized and the new

\footnotetext{
2 In this chapter, the term 'Qumran movement' refers to the movement responsible for composing, copying, and preserving the Dead Sea Scrolls, irrespective of whether this movement or parts of it were located at Khirbet Qumran. When we think of Qumran sectarianism, it matters whether we think of a small, unique, central community, or rather a network of parallel communities, or something else (e.g. chronologically subsequent communities; contemporary conflicting communities). The problem is not solved by any sectarian theory as such (cf. Collins in this volume).
} 
interpretation of life was experienced, the Qumran movement also developed such practices.

What type of personality did the Qumran movement form and esteem? What kind of perfection did they attempt to achieve? The investigator should look for values that contributed to an ideal personality. Here the highly idealized passage in the beginning of the Community Rule ( $1 \mathrm{QS}$ 1: 1-15), for example, provides suitable clues: the language is value-oriented (using the preposition le plus the infinitive) and it describes actions and sentiments to which the group aspired. We learn that the members are to tune their lives according to the divine will: their 'knowledge, strength, and wealth' $(1: 11-12)$ as well as their time (1: 14-15). Firmness and exactness are also praised: one should not turn away because of 'any fear, terror, or persecution that may occur during the time of Belial's dominion' (1QS 1: 17-18), and not to err 'to the right or the left' (1:15). The personality fashioned in this way is able to love or hate other persons according to the degree they deserve to be loved or hated (1: 9-11; cf. 9: 21); one identifies with other 'volunteers' of God.

The Damascus Document likewise supports the observation that a central value in the movement had to do with knowledge: education, guidance, and 'exact interpretation' (CD I2:, 3; 6: 14; 13: 7-13). A valued person, a 'hero', would be one who invested his/her time in studying (and was enlightened by the insights from God) and was thus able to follow the correct timings and take proper notice of holy space in harmony with the structure of the world. Knowledge was not to be kept to oneself but to be shared among the proper circle (1QS V8: 11-12, 17-18). A very similar value-orientation can be found in the rules about admission: the door into the movement opened when a person was determined to turn to the Law as it was revealed and taught in the movement (Jokiranta 2007). By contrast, accumulation of wealth, for example, was by no means desirable; on the contrary, it was associated with wickedness (CD 4: 17; 6: 15-17; 1QpHab 6: 1; 8: 10-12; 9: 4-5). A fuller analysis could take account of the types of human values present (see Schwartz 1994; 2001). It is noteworthy that some values might contradict each other: for example, control over people and personal achievement could clash with conformity and submission.

Louise Lawrence (2005) highlights virtuoso mentality and vocabulary in the Community Rule. Perfection was achieved through exercise, which takes place, most of all, in regular communal meals and gatherings, sharing of property, and through various rules that also controlled the body. In comparison to this document, the Hodayot contain, in Lawrence's opinion (2005: 97), 'low anthropology', which prevents the cultivation of virtuosity mentality. Confessing one's sins and acknowledging human frailty do not fit well with the ideas of perfection and insight. However, the very same confessional element is found at the beginning of the Community Rule as well as its final hymn, and can be seen to be one, central part of the social identity of the movement: this was the group that had heard the divine word, confessed its sins, and turned to God to overcome them. In human 
relationships, the virtuoso personality has the role of a master, whereas in the relationship to God, one displays humility, sensitivity, and receptivity (cf. major study on the creation of the sectarian self by Newsom 2004).

The formation of the virtuoso personality in the movement was effected in many other ways. Commonly shared stories of 'hero' figures are often necessary for the group to maintain positive self-esteem in the face of opposition. In the pesharim, the Teacher is perceived in a prototypical way (Pietersen 2005; Jokiranta 2006). This figure represented the maximal difference to out-groups: he was in conflict, rejected by the out-groups. At the same time, the portrayal of the Teacher crystallizes the similarities amongst in-group members: they were the possessors of divine revelation, persecuted but vindicated in the end. Social identity is never complete in the sense that group boundaries are constantly being rebuilt (Jokiranta 2005; 2007).

Segregation and separation as such are not unique to the groups of 'virtuosos'. Every group has social boundaries but the nature of these boundaries varies (instead of 'boundaries', Rambo [1993: 104] speaks about 'encapsulation strategies' common to all groups wishing to teach something new; Chalcraft [forthcoming] uses the term 'social closure'). Groups of 'virtuosos' can choose (although not completely freely) to be more or less open to outsiders in their organization. The advantage of a great exclusivism is the efficiency in the creation of virtuoso personalities: one is surrounded by models which all support the correct behaviour. The disadvantage of strong exclusivism is the risk of becoming less attractive to potential members and the loss of influence on the wider environment, perhaps also frightening some members out. Lawrence (2005) highlights the way in which the polemics in $1 \mathrm{QS}$ tends to concentrate on dissenting members rather than negatively defined out-group members: 'virtuosos' mostly tend to disapprove of those who come close to succeeding but fail.

In comparison to the Pharisaic groups, one difference in the virtuoso mentality of the Qumran movement-besides differences in specific interpretations of law and underlying theological beliefs-could be an aspect of collectivism. The ascetic perfection in the Qumran movement did not focus on pulling an individual member higher and higher up the ladder; it was rather the perfection of the collective that was the goal. Lawrence (2005: 90) states on the collective aspect of asceticism: 'The person initiated into the society envisioned in $1 \mathrm{QS}$ was forced to surrender spiritual, material and moral independence.' The 'ascetic' training did not happen in solitude but was built into a system in which the member could not cope alone.

\section{Case Study II: Weberian Impact on Society}

The next question concerns the way in which the virtuoso personalities formed in the Qumran movement might have had an impact on the wider society. David 
Chalcraft has shown initiative in this area, suggesting that, in a Weberian sociology (2007d: 76):

The Qumran materials can be approached with questions relating to the manner in which the Qumran sects selected and bred particular types of character and personality and how these transformations impacted in general on social, cultural and economic life.

Weber used the concepts 'inner-wordly' and 'outer-wordly' asceticism: worldaffirming and world-rejecting attitudes. In his Ancient Judaism, Weber claimed that 'inner-worldly asceticism' was not a lasting phenomenon in Judaism because of its ethical dualism, different ethics for insider and outsider relations (Weber 1952: 343; Schluchter 1989). In other words, the following of God's orders and will did not make an impact within the world but was withdrawn from the world since it was directed towards the insiders (in contrast to later Protestant Puritans who, for example, claimed superiority to other business dealers because of their trustworthiness; Weber 1952: 344). Proving one's piety lay in different matters from 'mastering the world'. According to Weber (1952: 382), the form of piety in the Maccabean times was, similarly, 'stripped off' from earlier forms of prophetic charisma.

Weber's famous thesis was that the predestination doctrine among Calvinists would produce 'salvation anxiety', insecurity about whether one was among the saved or not, and then 'inner-wordly' asceticism in order to prove worthy (see above). In other words, deterministic beliefs are likely to have social consequences.

The existence of deterministic beliefs in the Qumran texts justifies an investigation of a similar correlation. Deterministic beliefs in the scrolls could have motivated the members of the movement to 'assert' themselves in order to prove worthy. Dualistic language is one obvious indicator of deterministic beliefs: the world is divided between the forces of light and darkness, between the lot of God and lot of Belial, between truth and deceit (1QM 1: 1; 1QS 1: 9b-11a; 2: 1b-10; 3: 13-4: 26; 4Q266 1a-b i, 1). In the most pronounced way, the Discourse on Two Spirits in 1QS 3: 13-4: 26 expresses deterministic beliefs, proclaiming that 'they fulfil their destiny, a destiny impossible to change' (3: 16) and 'All people walk in both wisdom and foolishness-God has granted them (i.e. the spirits) dominion over humanity, so imparting knowledge of good [and evil, de]ciding the fate of every living being by the measure of which spirit predominates in [...] visitation' (1QS 4: 24-6). Each person has a predetermined portion in the spirit of truth and the spirit of deceit. The spirit of truth is recognizable in the works of righteousness, and the spirit of deceit is seen in the works of injustice and wickedness. People follow a due course, finding a reward or a punishment in the end.

The language of election is also common. The passage in CD 2: 1-13 addresses those who turn from their sins, but those who 'despise the statute' are determined to perish: they are not chosen by God, and before 'they were established' God knew their works. On the other hand, the (priestly) members are the 'chosen ones of 
Israel, those called by the name, who stand in the end of days' (CD 4:3-4). Similar pattern of refusing-to-turn-and-perishing and being-chosen-and-protected is found, for example, in the Psalms Pesher (4QpPs ${ }^{\mathrm{a}}$ 2: 1-5).

In applying the idea of 'predestination' to the Qumran movement, however, caution is needed (cf. Chalcraft $2007 \mathrm{~d}$ : 78 ): determinism, which is found in the Discourse on Two Spirits, is not found in a similar precision in other sectarian scrolls, and the scrolls' understandings of the after-life differ from Christian conceptions. In the Community Rule, the Discourse is a distinct section in this tradition, and not part of all the manuscripts (4QS ${ }^{\text {b,d }}$, see Metso 1997). Such systematic, deterministic beliefs can be a secondary justification of the segregation that had already taken place on other grounds (e.g. because of cultic and purity matters), and an attempt to hold on to the members who were in danger of losing their motivation. The underlying message conveyed through the Discourse is basically the following: the world is divided between good and evil, and one must choose one's side. Those who have chosen their side can still err or even be proven to be on the side of evil. On the one hand, the message justifies the setbacks within the 'righteous community': they are not yet completely purified and perfect but the reason for this imperfection is known and controlled by the community. On the other hand, the Discourse motivates the members to submit to the community discipline in order to prove that they are among the chosen ones (cf. Newsom 2004: 127). In the end, God is said to destroy the spirit of deceit (1QS 4: 19). Some ambiguity or even tension is accepted as to whom the final purification applies: on the one hand, 'God shall then purify all human deeds, and refine some of humanity' (1QS 4: 20); a few lines after this, it is clearly 'those following the perfect way' (1QS 4: 22) to whom the purification applies.

Such deterministic (even secondary) beliefs easily lead, not to a relaxation that there is nothing one can do in order to be 'saved' but to anxiety about whether one belongs to the lot of light, and thus to a tendency to reduce that anxiety (Chalcraft 2007d: 80). However, Chalcraft (2007d: 79-80) suggests that those kinds of deterministic beliefs which do not create a community of equals but rather a hierarchical community (with different portions of light, for example) can work against such a tendency or cause further sectarian developments where an inner, holy circle is further elevated above others. According to Weber, sects can transform individuals but this transformation does not extend to social and cultural change if the sect cherishes other-worldly asceticism (in contrast to the inner-worldly asceticism that was characteristic of Protestant sects which transferred the ascetic life from monasteries to secular life). Hierarchy and control are, according to Weberian reasoning, forces that work against the self-assertion tendency.

Nevertheless, further analysis might reveal mechanisms that would support the self-assertion tendency and its wider impact on forms of behaviour in the society. Hierarchical order was reestablished probably on an annual basis (1QS 5: 24) and 
could thus be surpassed. In the Weberian sociology, economic standing is one of the major objects of interest in reducing feelings of insecurity. 'In situations where the qualities esteemed by the sect relate to economic abilities as indications of moral standing it is clear that economic behaviour will be affected' (Chalcraft 2007d: 83). Judging from those passages where one's property (besides one's spirit and deeds) played a crucial role in the admission process (1QS 1: 13; CD 13: 7-13) and from the penalties imposed for lying about property (1QS 6: 24-5; CD 14: 20), economic issues were very much part of the agenda of the sect and its functioning. Yet, as noted above, individual wealth was not esteemed, but rather righteous redistribution of wealth.

A double ethic was operative: different rules applied to outsiders and insiders. The members gave up full rights to their property when entering the community and were careful not to share with the outsiders (1QS 5: 15-17; CD 13: 14-16; 12: 6-11). The minimum assumption is that the members would at least draw attention from outsiders because of their regulated economic exchange with them. It is possible that local groups formed a network that provided maintenance for travelling members - the sect could thus contribute to mobility and trans-local exchanges and, possibly, wider social change (Chalcraft 2007d: 85-8). Furthermore, the character of the maskil can be interpreted as an ideal sectarian personality, and the authority that he practised in economic matters most certainly included choices that were relevant also to outsiders (cf. 1QS 9: 21-4). Catherine Murphy (2002: 40-4, 83-4) has suggested that redeeming slaves and indebted persons would have been one activity on the basis of the duties of the maskil in CD 13: 9-10. In other words, the individual members did not triumph in the society by means of their economic prosperity but could assert themselves with their authoritarian decisions and knowledgeable economic choices in everyday life: which items to ban, which shopkeepers to trust, which relations to accept. Hierarchical order played a role in the movement but did not completely exclude opportunities for self-assertion as a 'knowing' personality.

In wider terms, the educative influence of the Qumran movement could have been substantive (cf. Chalcraft 2007d: 91). The cultivation of scriptural study, the emphasis on precise meanings of scripture, even a playful attitude towards the written word, distinctive scribal practices, creation of new literature-all of these matters transformed the personality of the members, attracted new members and possibly set standards for other sectarian groups to follow or to compete with. The type of personality they formed would have valued knowledge as well as the investment of time and effort in gaining this knowledge and the disciplined life that followed from it. To what extent sects were a response to the growth of literacy and competing interpretations of scripture, and to what extent sects contributed to 'rationalization' and more systematic forms of interpretations are questions to be kept in mind. 


\section{Types of Sects: Identifying the Group's Stance in Society}

The other approach into sectarianism to be illuminated here has been much more popular in biblical studies. According to this approach, the focus is not on the individual personality formation and its influence on society but on the interplay between the sect and the society and the types of sects emerging in different societies and settings. In one way, this perspective often views the sect in more responsive/reactive (rather than active/affirmative) ways: the sect is a protest against values or practices in society, and sects offer different solutions to the perceived problems. In the following, a few central theorists are introduced and their insights are used in three case studies.

\section{Troeltsch and Historical Christianity}

Ernst Troeltsch (1865-1923) was a German theologian and philosopher, whose studies are not directly useful for Qumran scholarship because of their strongly Christian framework. Yet, the Troeltschian attributes of sect and church have played a role in sect discussions (see Jokiranta 2001), and it is necessary to understand his approach to the sociology of sectarianism.

In his work The Social Teaching of the Christian Churches (1981), Troeltsch wanted to find out to what extent Christianity is sociologically conditioned and to what extent Christianity is itself an actively formative sociological principle (Troeltsch 1991: 372). Troeltsch contrasted the sect and the church as two distinct types of religious organization in the medieval period. Both of them were based on primitive Christianity and were partial representatives of it. A general distinction occurred in their attitude towards the world/state/society: the church desired to dominate all human life, whereas the sect, being organized in small groups, was indifferent, tolerant, or hostile towards the world. In the church, the Kingdom of God incorporated and controlled the state; in the sect, the Kingdom of God was in opposition to all secular institutions (for polarities, see Jokiranta 2001: 226-7). The sect type corresponded to the teaching of Jesus and the church type corresponded to the teaching of Paul.

The contrast between church and sect became more complicated in the era following the medieval period. Protestantism, although in line with the church type, modified the conception of the church: it relied on the state for influence and uniformity but, at the same time, sought to make the faith more subjective (Troeltsch 1981: 477, 1007-8). Troeltsch (1981: 348) recognized a mixed type, 'mysticism', which manifested itself sociologically as unorganized, individualized religiosity. 


\section{Sects and Pluralism}

In the past century, the sociology of sectarianism was confronted with the emergence of 'new religious movements' as well as secularization and religious conflicts, and the different conceptions of sect were modified accordingly. Not only were the characteristics of sect reconsidered but also its corollary of church was questioned. Postmodern Western societies did not have an established state-approved church that enjoyed a monopolistic position. Pluralism prevailed instead. Consequently, sects needed to be seen in a wider socio-cultural setting: their desire to withdraw was not from some orthodox teaching but from the world in general. In the American context, Niebuhr (1929) suggested that sects last only for a short time; within a generation they turn to a more denominational stance. Instead of the opposing types of 'church' and 'sect', some sociologists suggested taxonomies of religious organizations (e.g. Robertson 1972: 123; McGuire 1997), and 'cult' emerged as a new, frequently used category (e.g. Wallis 1975).

Alternatively, sociologists continued to use church-sect typology but modified the defining criteria or reduced them to one, placing it on a continuum. Johnson (1963) was among the first to emphasize the relation to the social environment as the defining criterion: church accepts the social environment in which it exists; sect rejects the social environment in which it exists. Many later studies adopted this view: sect was in tension with its socio-cultural environment (for an overview of the church-sect theory and its modification, see Bainbridge 1997: 38-42).

\section{Wilson and Sectarian Subtypes}

Bryan Wilson (1926-2004) stated that he was refining the ideal type construction of Troeltsch (Wilson 1973: 11-12). According to Wilson (1990: 46-7), sects stand in tension to their socio-cultural environment but are not necessarily otherwise similar to each other in their doctrine, organization, origins, and so on. The ideal typical character is most obvious in Wilson's typology of sectarian 'responses to evil', which, according to Wilson (1970: 35; 1982: 105), were not found in pure forms. These sectarian subtypes, however, helped to analyse the great variety of 'new religious movements'. Originally, Wilson formulated four subtypes of sects (four 'types of mission') in contemporary Christianity (1967). Later, he expanded this to seven (Wilson 1970); and to non-Christian contexts ('responses to evil'; Wilson 1973; 1982). The typology was thus designed to facilitate comparative study, although the starting point was within the Christian context.

'Responses' are various kinds of religious answers to perceived evil. It is noteworthy that the 'evil' is not defined. 'Introversionists' seek a purified community; 'conversionists' seek a transformed self; 'manipulationists' seek a transformed perception of evil; 'thaumaturgists' seek specific dispensations and miracles; 'reformists' 
seek to reform or change the world; 'revolutionists' seek a world transformed (by God); and 'utopians' seek a reconstruction of the world (by humans). In addition to these seven sectarian responses, the eighth, the dominant response in society, is acceptance of the world (Wilson 1973: 21-7). Wilson (1970: 13) sought to explain the conditions in which these types were most likely to arise, how they developed, and what influences they had in non-Western cultures. In a Weberian fashion, he was interested in explaining rationalization: once people come to the view that their ills were not caused by spirits or their own actions alone but by deficiencies in social structures, they could expect a communal transformation in these structures. When the expectation of the transformation was not fulfilled, people turned again to their own 'effort to work out salvation', but the experience could be the forerunner of more rational ideas about opportunities for structuring the new world (Wilson 1973: 7, 348-9).

In a similar way to Weber, Wilson identified in religious sects the disciplinary, collective impact but saw it to a varying extent in different types of sects, depending on varying conditions and as persisting for a varying period of time. For example, conversionist sects put more weight on the inner change of members than on a collective reworking. They emerged in individualistic societies and often became denominationalized, and thus endured for a long time. Revolutionist and introversionist ideas emerged as the result of a longer-lasting deprivation and they were very radical in their demands. Revolutionist sects were usually short-lived and thus did not make much of an impact.

The reader of Wilson's work might find the understanding of sect both as a schismatic, heretical offshoot from the church-at least, Wilson recognized this as a common, traditional understanding of Christian sects—and as a non-schismatic protest group which was in tension with the wider society (see Wilson 1970: 15-16, 26). In later studies, Wilson tended to work without any subtypes and instead developed the sociology of 'new religious movements' which protested against modernity (Wilson 1990, esp. 47; for Wilson's relation to Weber, see Chalcraft forthcoming). The 'responses' typology, however, has continued to enjoy great popularity in biblical studies.

\section{Case Study III: Sectarian Types and Changes}

Various scholars have identified in the Qumran corpus different sectarian 'responses to evil', following Wilson's (1973) typology of sectarian responses (e.g. Baumgarten 1997a; Grabbe 2007; Piovanelli 2007). The types are not, in my view, suitable for labelling ancient movements as such (see Jokiranta 2009; and cf. Craffert 2001). The concepts may, however, be used heuristically to pose questions about the nature of sectarianism and to see correlations or disconnections more clearly. Which response was more likely to be the primary one for the 
Qumran movement, if any? Did the movement's response change in the course of its history? Asking these questions requires that the responses are not just forms of rhetoric (cf. Robbins 1996, who uses responses as forms of social discourse) but identifiable social forms and behaviours.

Shemaryahu Talmon (1987) seemed to make a case paralleling Wilson's model from the revolutionist response to the introversionist: the first group was disappointed in its expectation of the imminent onset of the 'millennium' and only the emergence of a cohesive group around the Teacher of Righteousness signified the onset of the Qumran sect (in Talmon's terminology: 'community of renewed covenant'). Eyal Regev (2007) makes the case for the reverse. Even though we find eschatological expectations, periodic view of history, and calculations of the end in the Qumran documents, the separation was not explained by millennial disappointments. Instead, the separation in itself was a successful response to the evil experienced in the world: it met the members' immediate need for an environment where salvation could be realized. However, such separation was not easy to maintain in the long run, and the idea that this separation was temporary was a logical consequence. Regev claims that, 'while it is possible to point to millennial movements that did not withdraw from the outer society, it is more difficult to identify introversionist movements who develop no expectations about the future'. While this may be true, it is uncertain whether the apocalyptic and eschatological expectations ever developed into a full-blown urgent revolutionist response or rather remained as a living but non-specific sense of the end. Taking a closer look at Wilson's two types may illuminate the issue.

Wilson's typology suggested that introversionist and revolutionist responses emerge in very different cultural conditions. A revolutionist response is found frequently in less-developed societies whereas introversionism usually requires the idea that religion is a private commitment. An introversionist response seeks to maximize withdrawal from the world. Holiness is characteristic of both individual members and the community life; individual holiness depends on community holiness. History is preordained, and the world can no longer be saved. Outsiders and potential converts are treated suspiciously and as potentially contaminating. Those introversionist sects that had not withdrawn into colonies insulated themselves by other means: rules about associating with outsiders, distinctive dress, manner of speaking, endogamy, and particular professions.

The worldview and operation in the revolutionist response are characterized by a sense of urgency (often triggered by cultural change or oppression): the culmination of time is coming, and the truth must be proclaimed before this. Some of the sects Wilson studied had precise predictions of the end, others were more vague about the eschaton. The imminent coming of the saviour prevented any major attempts to change the world as such. Evil in the world was seen as a marker of the fulfilment of time. 
It is noteworthy that, according to Wilson, the introversionist response among less-developed peoples may not display similar exclusivism as among modern Christian sects but rather borrow from tribal or ethnic structure. It can be a secondary response, following the revolutionist, after a disappointment. But it can also occur independently: 'It may be withdrawal from the wider society of a group of people who share a similar sense of disenchantment with the world.' Often it then relies, in Wilson's view, on a prophet who has a compelling message but who does not colour this with a sense of urgency and makes no promises of an imminent, miraculous change.

The investigator should thus pay attention to the relationship between beliefs in the coming eschatological turn (revolutionist response) and beliefs in a 'pure' community (introversionist response) as providing resolution to the evils in the world in the Qumran texts. Periodization of history is typical of all apocalyptic literature, and Qumran apocalyptic texts make no exception-as such, it cannot be interpreted as a marker of a revolutionist response. Scholars differ in their view of whether figures like the ' 390 years' of the Damascus Document (CD 1: 5-6) should be interpreted as reflecting exact expectations of the time of divine intervention or rather as more vague, symbolic language drawing on biblical pre-texts and contributing to a particular worldview. The War Scroll is an example of a vivid expectation of a ritually pure and orderly battle in the end of times (following similar models of eschatological war, see Erho 2009), but hardly a text attempting to convince people that the end is at hand and they must choose their side. Even though the war is divided in periods of years (forty years altogether), the time of the commencement of the war is not reported to the reader; the reader only learns that the set times are known by God and revealed to the chosen ones (1QM 13: 14; 11: 7-8).

Closest to exact expectations of the end in the rule texts comes the passage of the Damascus Document where the final period is seen to start from the death of the Teacher and last about forty years until the adversaries are dead (CD 20: 13-22). However, this is clearly not the belief on which the movement was founded; rather it seems a secondary development, to motivate the members to stay alert in order to avoid the coming judgement. Even here, the figure of forty years carries symbolic connotations, and the prediction allows for many possible interpretations (e.g. whether only adversaries of the Teacher will die, or whether the divine intervention means a wider judgement).

Evidence for the introversionist response in the Qumran texts is much more overt: the community is the means to overcome evil. God chose them, revealed his truth to them and atones for them: 'God in his wonderful mysteries atoned for their iniquity and forgave their sin and built them a sure house in Israel, such as never stood from the earliest times until now' (CD 3: 18-20). They are perfect in holiness. Communal purity and individual purity are closely linked, and the outsiders are cursed: 'And this is the judgement for all those who entered the 
congregation of the men of perfect holiness but recoiled from doing the regulations of the upright: he is the man "who has melted in the midst of a furnace"' (CD 20: 1-3; cf. 1QS 8: 20-9: 2). Community building goes together with separation: 'This is the rule for the men of the yahad who volunteer to turn from all evil and to hold fast to all that He, by His good will, has commanded. They are to separate from the congregation of the men of injustice. They are to come together with respect to Law and wealth' (1QS 5: 1-2). Even the War Scroll sees the chosen ones as the locus of truth (1QM 13: 9-13).

Introversionist ideas and language are everywhere in the rule texts but we should not draw hasty conclusions about their sociological significance. When we turn to other genres, the sense of a pure community as the resolution to evil becomes less clear. In many hymns of the Hodayot, the speaker negates himself for the glory of God; human nothingness is contrasted with divine wisdom, and a community is hardly mentioned as a locus of salvation (e.g. $1 \mathrm{QH}^{\mathrm{a}}$ 5: 20-3; 11: 19-21; 18: 3-7; see Newsom 2004: 239-40, 273). The speaker is alone and persecuted (12: 9) but his distress reveals God in his might (10: 20-30). The community envisioned is the heavenly community (11: $21-3$ ).

On the other hand, the Hodayot where a leader figure plays a role actualize his leadership, creating a community of disciples $\left(1 \mathrm{QH}^{\mathrm{a}} 12\right.$ : $24-9$; 15: 10; cf. Newsom 2004: 299). Furthermore, in some community hymns, the speaker who has acquired new insight is brought closer to other, similarly enlightened individuals $\left(1 \mathrm{QH}^{\mathrm{a}}\right.$ 6: 18). Yet, it is not the community but the knowledge and new perception about the human state and divine righteousness that are highly regarded-they are presented as keys to overcome evil $\left(1 \mathrm{QH}^{\mathrm{a}} 8: 20-1\right)$. The exception is perhaps the hodayah in column 14, which has strong remnant theology: the 'men of Your council' are a distinct group among 'children of men' (14: 11) and have all truth and glory. The significance of this human community, however, is not limited to insiders: they are the mediators of divine truth to the world (14: 15-16).

The Hodayot and the rule texts do not necessarily contradict each other or represent different responses. The best sectarian can be made by the creation of the 'self' that is totally committed to the divine agent whereas the individual is, in fact, completely dependent on the sect (cf. Newsom 2004: 296-7). Therefore, sentiments such as those found in the Hodayot could be interpreted within the scope of an introversionist response.

On the other hand, it is possible to identify factors that rather suggest a utopian response, perhaps at an earlier stage, before a full introversionist response, or as strands within the movement. In the utopian response, humans rebuild the world themselves. According to Wilson (1970: 40), the utopian response is neither withdrawal from the world nor a desire to overturn it but to return to the basic principles by which the creator intended people to live. This response seeks to 'rediscover the model for the way of life for all men', and thus the community is not a defence mechanism for preserving its own piety. The community is not so 
much a location for salvation as an agency for salvation. In comparison, introversionist sects want to get away from the world.

Two passages in the Community Rule that state the purpose of the community, 1QS 5 and 1 QS 8, are illuminative from this perspective. 1QS 5: 6 defines the task as 'to atone for all those who volunteer for holiness in Aaron and for the house of truth in Israel and those who join them in yahad' whereas, according to $1 \mathrm{QS} 8$, which may preserve an earlier formulation of the 'programme' of the movement, they are 'to preserve faithfulness in the land with self-control and a broken spirit, atoning for sin by working justice and suffering affliction' ( $8: 3-4 ; \mathrm{cf} .8: 6 ; 9: 4-5)$. In the first passage, atonement concerns the inside members, whereas the latter formulation reflects the belief in the wider importance of the movement: in the time of wickedness, they uphold the covenant (8:10) and preserve the God-given rules, for the benefit of the land. Their withdrawal is preparing for the way (the model of living to be realized in the eschatological era), not isolation for its own sake. Other evidence could also be interpreted from this point of view. For example, the emphasis on the ability to love what God loves and to hate what $\mathrm{He}$ hates $\left(1 \mathrm{QH}{ }^{\mathrm{a}}\right.$ 6: 18-21; $\left.1 \mathrm{QS} 1: 3-4 ; 3: 26-4: 1 ; 9: 21\right)$ means the ability to establish sound moral (and ritual) principles of what is right and wrong in society.

If this suggestion is valid, it is conceivable that a utopian response and the excitement of building the new world turns into an introversionist response and inverted concern of the members' holiness when time passes and the movement does not receive recognition, or when a leadership emerges that demands a stronger denial of previous commitments. One marker of a stricter degree of exclusivity are those passages that begin to regulate, in clear terms, contacts with outsiders (1QS 5: 10-20) and matters of apostasy (1QS 8: 20-9: 2). In other words, qualification and motivation to be in the movement were not sufficient, one had to show commitment by denying former contacts.

What is the benefit of such an analysis of sectarian responses to 'evil'? A study of societal conditions where each response is likely to emerge would require a fuller appreciation of Wilson's work, but as it turns out he did not pay equal attention to all responses in order to provide sufficient comparative data-and transferring his observations to the ancient setting would be very difficult. Nevertheless, such conceptual responses facilitate hypothesizing about the primary and secondary forms in the Qumran movement.

\section{Stark and Bainbridge and the Idea of Movements}

There is wide acknowledgement among scientists of religion of the role of innovation in religious traditions. Religions always contain conflicts, small groups, and novel beliefs that challenge them to reform, renew, and reinvent. Religious movements are 
rightly called movements: they are part of a constant and ongoing movement in religions whereby religions react to and effect cultural changes.

On these assumptions, Rodney Stark and William Sims Bainbridge's (1985; 1987) built their theory of religion in the 1980s. The theory is an exchange theory (or a 'rational choice theory'): it assumes that religion arises 'through social exchanges in which individuals seek rewards and attempt to avoid costs' (Bainbridge 1997: 404; for a critical view on the rational choice theory, see Beckford 2003: 167-71). Since rewards exist in limited quantity, people accept compensators, explanations that are treated as rewards. Religion is 'a system of general compensators based on supernatural assumptions' (Stark and Bainbridge 1987: 39; but see the slight reformulation of the theory and the language of compensators in Stark 1999).

Stark and Bainbridge's ideas on sects belong to this theoretical perspective and are also based on empirical studies of religious bodies (1987: 153). According to the theory (Stark and Bainbridge 1985: 49; Bainbridge 1997: 24), a 'sect movement' is a deviant religious organization with traditional beliefs and practices. A 'cult movement' is a deviant religious organization with novel beliefs and practices. A 'church' (or denomination) is a conventional religious organization. Deviance, or tension, means that a group develops or maintains a culture at variance with the dominant culture of society, incurring costs for those who maintain it. That is, at the lowtension end, we find 'religious institutions', which are close to or nearly identical with the socio-cultural environment (social structures, roles, norms, values, and activities of the society). Institutions adapt to change. At the high-tension end, we find 'religious movements' (sects and cults), which attempt to cause or prevent social change. Religious groups are thus always related to their context; no 'essence' can be presented of either religious institutions or religious movements.

In their Future of Religion, Stark and Bainbridge (1985: 48-67) outline three elements that can be empirically used for measuring tension. The first is difference: the extent to which the behaviour and practices of the members are different from the majority, or from the standards of the powerful members of the societysectarians follow deviant norms. The second is antagonism towards other religious groups or society, usually expressed in particularistic beliefs denying the legitimacy of other competing groups, and resulting in rejection by them. The third is separation, restriction of social relations and contacts mainly to in-group members. In a later study, Bainbridge (1997: 42-7) speaks of 'aspects of tension' that can be measured: these are variations in beliefs, behaviour, and social relations (corresponding roughly to Rambo's [1993: 106] 'physical, social and ideological encapsulation'). The three elements/aspects are in close interplay and each one of them adds to tension, usually by strengthening one or both of the other elements/ aspects as well.

Once a movement is classified as being at the high-tension or at the lowtension end, one can proceed to analyse other questions, such as the social class of the members and its correlation to the degree of tension. The results suggest that 
high-tension groups generally attract people who suffer from 'relative deprivation,' i.e. deprivation of some valued reward, relative in the sense that the lack of rewards is judged in comparison to something else, e.g. to close associates or one's standard in the past. High-tension movements offer specific compensators that substitute for wealth, power, and status, whereas low-tension groups tend to offer concrete rewards. The higher the tension, the greater the number and perceived value of the compensators (Stark and Bainbridge 1985: 142-9; Bainbridge 1997: 50-9).

\section{Case Study IV: Sectarian Tension in the Community Rule and the Damascus Document}

Whereas Wilson's work focused on the type of religiosity (type of response), Stark and Bainbridge's work directs one to understand groups on a continuum with a varying degree of 'sectarianism' or tension. Group boundaries sociologically perceived are not only ideological but often materialize in social forms. Therefore, observing ideological tension in texts (deviant beliefs, polemic language, dualistic ideology) is not sufficient to demonstrate that a group existed which viewed itself as a distinct social group and which was in tension with the surrounding societysocial boundaries are needed too. Stark and Bainbridge's elements of tension provide a useful conceptual tool for analysing social boundaries as regards to their degree of tension: a sectarian group is one in which antagonism is strong, social norms deviant, and social relations restricted. Surely, at the same time, a sect in tension can also capture some core values of the larger society (cf. Ling 2004: 242-3). Being in high tension does not mean that the sect is in open conflict with the surrounding society.

The greatest advantage of the tension with perspective comes from the contextdependent nature of sectarianism. A sect is not a sect as such but in relation to other entities and societal change. Whereas some scholars have stressed the basic difference between the Judaism of the Damascus Document and the Community Rule, seeing in them full 'systems' (e.g. Davies 2000), Stark and Bainbridge's perspective takes both documents and views their evidence in interaction with the assumed societal context.

From this point of view, the sectarianisms as reflected in the Damascus Document and the Community Rule were much closer to each other than often thought, as argued by Cecilia Wassen and Jutta Jokiranta (2007). Both documents reflect a relatively high tension in their environment. First, they express antagonism towards outsiders and include particularistic beliefs, which occasionally were very harsh: the world was seen to be divided in the lots of good and evil, and the dividing line went between the members and the non-members. Second, judging from the available evidence of Second Temple practices, as well as using an 
informed imagination of a range of existing possibilities, the Qumran halakhah was, in many respects, different from others: strict Sabbath observance, a special calendar, expansion of purity rules, ban of polygamy and uncle-niece marriages, restrictions concerning the temple cult, and the like. High ideals and goals brought along other deviant practices and corresponding norms: communal property and business management, study sessions, meals in purity, oaths, surveillance and reproof, new hierarchical order and responsibilities. Third, social separation occurred when members avoided contacts with outsiders and mingled mostly with insiders. The Damascus Document testifies to specific forms of separation without any evidence that the groups behind them would have lived physically apart. For example, the leaders in the movement controlled marriage contracts and economic exchange.

Defining the degree of tension is in no way unproblematic and any definition must take careful note of the counterpart, the socio-cultural environment (see further discussion by Jokiranta 2005). Rather than assuming an 'essence' of sectarianism or postulating a monolithic Judaism against which the sects protested, it is more useful to examine the groups' reactions to societal change and their degrees of tension.

\section{Case Study V: 'Conversion' and Persistence}

Two further points of sociological interest are: What attracted people into the Qumran movement? And who would have been a potential initiate? These two questions are related and provide macro- and micro-perspectives into the phenomenon of 'conversion'. The first question seeks to find the societal conditions where sectarianism was possible and where sects were seen to address certain societal needs. From a Weberian perspective, for example, sects provided a means to live out heroism in the Maccabean era. Many scholars have emphasized that the emergence of sects belonged generically together with those developments that took place earlier in the post-exilic period (Talmon 1987: 606; Blenkinsopp 2005: 10-11). The loss of the king-state generated a hunger for divine intervention. Similarly, Sheldon Isenberg's (1974) study on millenarianism in Greco-Roman Palestine took the Qumran sect as one among other dissatisfied groups that emerged when a millenarian prophet convinced the group of a new solution. Others have stressed the importance of the new situation in the Hasmonean era (Baumgarten 1997a) and the social stratification in Judaea (Ling 2004: 244-9). Various scholarly reconstructions of the origins of the Qumran movement can receive support from various sociological theories: for example, Duhaime (1993) applied C. Y. Glock's theory of five kinds of deprivations to view different theories of the Qumran sect. 
The second question enjoys a long tradition of research into understanding the process of joining a new religious movement and the minimum requirements for a full conversion to take place. 'Conversion' is a good example of both the problems and prospects of using modern research in the study of ancient phenomena. The concept of 'conversion' can lead the interpreter of ancient texts astray if it carries connotations belonging to modern religious traditions, quite alien to the antique world. Yet, the phenomenon exists, and conceptualizing it in the study of antiquity can be fruitful (cf., Crook 2004, who has argued that Paul's conversion is better conceived in terms of changes in loyalty in a patron-client relationship).

Along these lines, we first need to specify what we mean when we think of joining the Qumran movement. According to Lewis Rambo (1993: 12-14), there are various types of conversion. Apostasy is repudiation of a religious tradition; intensification is the revitalized commitment to a faith with which the convert has had previous contact; affiliation is the change from no or minimal religious commitment to full involvement with an institution or community; institutional transition is the change from one community to another within a major tradition; tradition transition is the change from one major religious tradition to another.

The rule documents include no specific data about how a potential convert was first introduced to and then became fascinated with the movement (cf. economic and educational attraction above). Three of the above-mentioned conversion types are most likely: intensification, affiliation, and institutional transition (tradition transition would apply to proselytes into Judaism who then became members). (1) Intensification is clear in the way the texts speak about 'returning': membership has to do with the core values of the wider religious tradition (e.g. covenant). Also the keen interest in the purity rules is intensification of otherwise familiar rules: new converts would have learned to commit themselves in an intensified way. Children of the members would also fall into this category. (2) Affiliation in the sense defined above could apply to members who, in their earlier life, were ignorant of the various types of laws or did not have access to them-such a population is often in the Second Temple setting construed as the 'people of the land'. Hodayot conceive of 'simple ones' who receive knowledge $\left(1 \mathrm{QH}^{\mathrm{a}} 5: 2 ; 10: 9\right)$. The Nahum Pesher and the Habakkuk Pesher also mention the 'simple ones' who were led astray (1QpNah 3: 5; $1 \mathrm{QpHab}$ 12: 4). The passage in $1 \mathrm{QS}$ 2: 11-3: 12 is a polemic against artificial conversion, suggesting a sort of person seeking personal benefit or other things deemed undesirable. (3) Institutional transition is conceivable as movement from one sect to another: the Pharisees were perhaps the closest competitors and a flow from one movement to the other was likely. However, membership in such voluntary associations was not 'institutional' in the modern sense of the word; rather one could imagine a teacher with a following or a tradition of practices among families and elites (Sivertsev 2005). 
Scholars of conversion have comprehended it as a process with several stages. For example, according to Lofland and Stark (1965), seven stages are necessary and sufficient for conversion:

The converts must (1) experience enduring, acutely felt tensions (2) within a religious problem-solving perspective (3) that leads them to define themselves as religious seekers, (4) encountering the new group at a turning point in their lives, (5) wherein an affective bond is formed with one or more converts (6) where extra cult attachments are absent or neutralized ( 7 ) and where, if they are to become deployable agents, they are exposed to intensive interaction.

Can such a modern model facilitate the understanding of ancient people and their social movements? George Brooke (2005) is clearly aware of the problems involved with such an enterprise. He reads the Qumran evidence heuristically in light of Lofland and Stark's theory of seven stages but does not investigate directly the conversion process as such. Rather, he draws attention to a specific question concerning conversion: how was scripture used to justify and facilitate the process of conversion? Brooke explains how the use of scripture reflects this process. For example, (1) scriptural plurality might have been one factor in the experienced tension, which was, however, harnessed in the service of the Qumran movement in attracting new members. (2) The movement looked at the past in the light of scripture, which shows that the ills in the social order were considered to be religious in nature. $(3-4)$ Conventional religious solutions were considered inadequate or false, and the seekers came to encounter the new movement on the basis of common interests in scriptures: the movement was possibly known for its literate culture. For stages 5-7, Brooke argues that, as a result of communal living and the process of admission, the novice created strong bonds with insiders and negated previous bonds with outsiders. Scriptural labels and the study of scriptures provided suitable means for identification and attachments.

Brooke's suggestion is significant: the potential convert shared an interest in looking at reality in the light of the scriptures, and because of this, other types of persons would not be attracted to the movement in the first place. However, this brings forth a further question. Why would such a potential convert choose this particular movement and not some other scripturally oriented movement which probably existed (cf. 'common sectarian matrix' by Lim 2002: 83-5)? Moreover, it is questionable to what extent an individual's conversion stages and their scriptural justification are directly identifiable in the texts-what can be identified is rather the ways in which the collective justified its values and deviance. Collective ways may or may not have a correlation to how an individual found justification in the conversion process.

Stark and Bainbridge (1987: 195-238) revisit Lofland and Stark's theory of conversion. They prefer to speak about affiliating, including both aspects of recruiting and joining, rather than 'conversion', which, in their mind, implies 
that a person changes in a profound way. Conversion is the person's belief in the change-and thus a compensator rather than a direct reward (cf. above, and Wilson 1990: 180-1). They set the theory in a wider perspective of human exchange. To summarize their argument: people are likely to join high-tension groups to the extent that they are relatively deprived (i.e. in comparison to others, they feel deprived of some valuable reward) but they do not resort to open struggle for these rewards, since the elite is powerful enough to suppress rebellion; therefore these people must seek a non-political solution. Furthermore, people are likely to join high-tension groups to the extent they, at a turning point in their lives (positive or negative), are low in social relationships and come to develop new social relations with the sect members who offer more rewards/compensators than costs.

Thus, two correctives are made to the view above. First, active religious seeking is not a necessary condition for joining sects-affiliation with the sect members is sometimes enough. Nevertheless, it is important for the insiders to perceive the newcomers as religious seekers who found what they were looking for (Stark and Bainbridge 1987: 224). In the Qumran sources, this 'seeking-finding' pattern can be identified, for instance, in the confessing of the sins of ancestors (1QS 1: 22-2: 1; CD 20: 27-31) as well as the perception of outsiders as those who have not sought the truth in the first place (1QS 5: 11).

Secondly, new social ties must be sufficiently rewarding. 'Religious seekers will not accept new compensators, and be willing to expend costs over time to maintain them, until they experience repeated rewarding exchanges with other persons who already accept the compensators' (Stark and Bainbridge 1987: 231). 'Rewarding exchanges' in the case of the Qumran movement presents somewhat of a problem: if the members separated from the outsiders, how did the potential converts have such experiences? The rule texts speak a lot about admission into the movement, but they are mostly concerned with the examination of the newcomer, with the moulding of this personality and drawing boundaries against outsiders, including apostates. Secrecy and strictly regulated contacts with outsiders would not encourage any lively and open recruitment. However, the task of the maskil was to walk righteously with 'all living' - and perhaps to identify those with the most potential to qualify as 'children of righteousness' (1QS 9: 12-21; CD 12: 21). New members were perhaps recruited most efficiently through kinship structures: children of members had to enrol (1QSa 1: 8-9). The voluntary nature of the association is clear since the second or later generations were not automatically members. To some extent, the Qumran sources use fictive kinship terminology (but not of 'brotherhood': Jokiranta and Wassen 2009): this could be one sign of the new ties outweighing the earlier ones, e.g. offering a new 'family' to members who had lost their family or their connection with it.

Furthermore, the theory claims that people who are unsatisfied with the existing religious explanation will seek a new one but will try to keep their cultural system otherwise unchanged. This would fit with Brooke's suggestion that the members of 
the Qumran movement were already inclined to look for a scriptural explanation-but we must note one reservation: we cannot directly work backwards, drawing a pre-member profile on the basis of the member profile (sources), since new members also come to accept other explanations than those specifically addressing their needs. Nevertheless, members already in high-tension groups would be more likely to join a movement with similar or a little higher tension. Costs in joining high-tension groups can also be reduced, according to Stark and Bainbridge (1987: 205), by masking the deviance, e.g. by organizing as a secret society. Secrecy in the Qumran movement could very well have this role, too (see also Pietersen 2005, and his application of the sociology of deviance to those strategies in the pesharim that labelled prevailing religious solutions as inadequate and justified deviant responses).

These theoretical explanations concerning conversion are somewhat abstract but provide suggestions of what to look for in the sources. A theory suggesting universal patterns (of conversion) is to be used with care: it should not be forced on the evidence. Rather, the investigator may ask to what extent his/her evidence seems to support the theory. Furthermore, alternative ways of thinking about 'conversion' might prove fruitful. For example, Rambo (1993: 121-3) reminds us of the importance of role change in the conversion process. A role includes expectations of behaviour in a certain position. This perspective brings forth the contextual character of conversion: expectations are derived socially, not individually. Moreover, textual scholars often pay attention to language-new terminology, labels, polemics - as forms of creating a new convert. Attention to ritual-prescribed action - might be equally important in the study of recruitment, conversion, and survival of the movement (Rambo 1993: 113-18). The study of rituals is one area where not very much work has yet been done from a sociological perspective. Lastly, comparative studies on sects and conversion processes are a valuable source of inspiration, also to scholars of antiquity. Here, Albert Baumgarten (1997a), and Regev (2007) are to be mentioned as pioneers highlighting the most fascinating analogies to Qumran scholars.

\section{Concluding Remarks}

We have seen that, within sociology, 'sect' can mean a variety of things and be used in a variety of ways. In light of the above sociological treatments of sectarianism, the Qumran movement, represented especially in the rule documents, can be approached from various 'sectarian' perspectives. In the Weberian sense, it had a 
voluntary membership, acquired by qualification, and it cultivated a certain kind of personality. In the Troeltschian sense, it was of a sect type due to its non-universalistic stance: there is little evidence of a desire to conquer the world and expand its belief system and lifestyle to the masses. In the Wilsonian sense, the Qumran movement stood in tension to the wider socio-cultural environment-it sought, in my view, to present an alternative subculture. Which subtype (response to evil) it might have represented, if any, is another matter. Following Stark and Bainbridge, the Qumran movement was a sectarian movement since it rejected cultural change and demanded a return to biblical values.

Each sociological framework represents specific aspects of sectarianism, the merits of which will be lost if only the definitions are being compared. For Weber, sect-as a voluntary association-was not necessarily in great tension to the outer world but offered a way to demonstrate values of the world whereas, for many others, sect is defined on the basis of the tension to the world. For Stark and Bainbridge, sectarianism is created only in relation to non-sectarianism in a particular setting (deviance defined by societal norms and attitudes towards cultural change), which could result in concrete cases which have nothing to do with the Weberian sect and human tendency to asceticism and heroism. First of all, biblical scholars should be aware of these differences. Secondly, choices between different frameworks can possibly be made, independent of their applications in antiquity. Sociology as a modern discipline was primarily interested in modernity: what has made the present era distinct and discontinuous to the 'pre-modern'? Sect studies were part of this enterprise: for Weber, sectarianism was one aspect of understanding those modes of thought and behaviour that characterized the rise of the capitalist ethos. From this perspective, we could say that the 'sect' did not yet exist in antiquity - a new ideal type would be needed.

Mixing different theorists is tempting but not unproblematic. For example, in his The Flourishing of Jewish Sects, Albert Baumgarten relies on Weber, Wilson, and Stark and Bainbridge. He creates his own definition of a sect as 'a voluntary association of protest, which utilizes boundary marking mechanisms to distinguish between its own members and those otherwise normally regarded as belonging to the same national or religious entity' (Baumgarten 1997a: 7). However, this definition is not consistently followed. For example, the voluntary nature and boundary marking allow the inclusion of the Pharisees among sects (a Weberian understanding of virtuosos). In terms of the 'protest', however, the more moderate tension of the Pharisees would make them less sectarian according to the Stark and Bainbridge framework. Because of this, Baumgarten uses Wilson's responses to make distinctions between sects. Pharisees and Sadducees are 'reformist sects'. This is not the way in which Wilson used the term: to him, a reformist response was a secondary response, born after revolutionist or introversionist disappointments. The Weberian understanding would be sufficient to highlight similarities in the 
boundary marking and values of the various groups, which Baumgarten's analysis demonstrates very well.

More important than commonly agreed definitions and concepts is the desire to cultivate a sociologically informed imagination. The analysis should not cease with defining a sect. In my view, Weber leads us to think sociologically about the rationalization of the Second Temple period, for example, whereas Stark and Bainbridge challenge commonly held assumptions on sects, but their universalistic propositions should not be taken at face value. Wilson's responses were not meant to be used for historical explanation and they should be used heuristically, not as classificatory labels for ancient groups.

What the sociological approaches, at their best, offer is the inspiration and informed imagination to theorize, in an explicit and precise manner, about the social phenomena in the Qumran movement and Second Temple Judaism. Often such perspectives offer us meta-knowledge: of which wider phenomena the texts are part. Their purpose is to explicate unsaid assumptions, clarify used concepts, and propose new angles for looking at the evidence.

\section{Suggested Reading}

Studies on sectarianism by Weber, Troeltsch, Wilson, Stark, and Bainbridge are major sources for methodological reflection and sociological imagination. However, doing sociological analysis of ancient texts is not restricted to the study of sectarianism (as in this article), and a wider perspective requires further tools and a greater variety of themes (social stratification, leadership, community, gender, ethnicity, ritual, honour; see e.g. Lee and Newby 1983; Bauman and May 2001; Scott and Marshall 2005).

Qumran sectarianism has not been extensively explored from specifically sociological perspectives. Regev (2007) compares the sectarianism of the Community Rule and the Damascus Document, utilizing also comparative data of modern sects. Baumgarten has written several articles relevant to various aspects of sectarianism (1992; 1997b; 1998a; 1998b). Weberian sociology on sectarianism is explored anew and sociological imagination on the Qumran movement is practised in Chalcraft (2007a). Lawrence and Aguilar (2004) and Campbell, Lyons, and Pietersen (2005) include several essays important for developing new methodologies.

Previous social-scientific approaches in other fields of biblical studies are not to be copied as such but acquaintance with methodological discussion can be beneficial (see Mayes 1989; Blasi, Duhaime, and Turcotte 2002; Esler and Hagedorn 2006). 


\section{BIBLIOGRAPHY}

Bainbridge, William Sims (1997). The Sociology of Religious Movements. New York: Routledge.

Bauman, Zygmunt and Tim May (2001). Thinking Sociologically. Oxford: Blackwell Publishing.

Baumgarten, Albert I. (1992). 'The Rule of the Martian as Applied to Qumran'. Israel Oriental Studies XIV: 121-42.

- (1997a). The Flourishing of Jewish Sects in the Maccabean Era: An Interpretation. Supplements to the Journal for the Study of Judaism 55. Leiden: Brill.

(1997b). 'The Zadokite Priests at Qumran: A Reconsideration,' Dead Sea Discoveries, 4(1): 137-156.

(1998a). 'Finding Oneself in a Sectarian Context: A Sectarian's Food and Its Implications' in A. I. Baumgarten, J. Assmann, and G. G. Stroumsa, eds., Self, Soul, and Body in Religious Experience. Studies in the History of Religions (Numen book series) 78. Leiden: Brill, pp. 125-47.

(1998b). 'Graeco-Roman Voluntary Associations and Ancient Jewish Sects' in M. Goodman, ed., Jews in a Graeco-Roman World. Oxford: Oxford University Press, pp. 93-111.

BeCKFord, JAmes A. (2003). Social Theory and Religion. Cambridge: Cambridge University Press.

Berquist, Jon L. (1995). Judaism in Persia's Shadow: A Social and Historical Approach. Minneapolis, MN: Fortress Press.

Blasi, Anthony J., Jean Duhaime, and Paul-Andre Turcotte, eds. (2002). Handbook of Early Christianity: Social Science Approaches. Walnut Creek, CA: Altamira Press.

Blenkinsopp, Joseph (2005). 'The Qumran Sect in the Context of Second Temple Sectarianism' in J. G. Campbell, W. J. Lyons, and L. K. Petersen, eds., New Directions in Qumran Studies: Proceedings of the Bristol Colloquium on the Dead Sea Scrolls, 8-10 September. London: T\&T Clark International, pp. 10-25.

Brooke, George J. (2005). 'Justifying Deviance: The Place of Scripture in Converting to the Qumran Self-Understanding' in K. De Troyer and A. Lange, eds., Reading the Present: Scriptural Interpretation and the Contemporary in the Texts of the Judean Desert. Atlanta, GA: SBL, pp. 73-87.

Bruun, H. H. (2001). 'Weber on Rickert: From Value Relation to Ideal Type'. Max Weber Studies 1.2: 138-160.

Campbell, Jonathan G., William John Lyons, and Lloyd K. Pietersen, eds. (2005). New Directions in Qumran Studies: Proceedings of the Bristol Colloquium on the Dead Scrolls, 8-10 September. London: T\&T Clark International.

Chalcraft, David J. (1997). 'Introduction' in D. J. Chalcraft, ed., Social-Scientific Old Testament Criticism: A Sheffield Reader. Sheffield: Sheffield Academic Press, pp. 13-19.

- ed. (2007a). Sectarianism in Early Judaism: Sociological Advances. London: Equinox.

- (2007b). 'The Development of Weber's Sociology of Sects' in D. J. Chalcraft, ed., Sectarianism in Early Judaism: Sociological Advances. London: Equinox, pp. 26-51.

- (2007c). 'Max Weber' in J. Scott, ed., Fifty Key Sociologists: The Formative Theorists. London: Routledge, pp. 203-9. 
Chalcraft, David J.(2007d). 'Towards a Weberian Sociology of the Qumran Sects' in D. J. Chalcraft, ed., Sectarianism in Early Judaism: Sociological Advances. London: Equinox, pp. 74-105.

(forthcoming). 'Is a Historical Comparative Sociology of (Jewish) Sects Possible?' in S. Stern, ed., Sectarianism in Jewish History. Leiden: Brill.

Craffert, Pieter F. (2001). 'An Exercise in the Critical Use of Models: The "Goodness of Fit" of Wilson's Sect Model' in J. J. Pilch, ed., Social Scientific Models for Interpreting the Bible: Essays by the Context Group in Honor of Bruce J. Malina. Leiden: Brill, pp. 21-46.

Croок, ZeвA A. (2004). Reconceptualising Conversion: Patronage, Loyalty and Conversion in the Religions of the Ancient Mediterranean. Beihefte zur Zeitschrift für die neutestamentliche Wissenschaft und die Kunde der älteren Kirche 130. Berlin: Walter deGruyter.

Davies, Philip R. (2000). 'The Judaism(s) of the Damascus Document' in J. M. Baumgarten, E. G. Chazon, and A. Pinnick (eds.), The Damascus Document: A Centennial of Discovery; Proceedings of the Third International Symposium of the Orion Center for the Study of the Dead Sea Scrolls and Associated Literature, 4-8 February, 1998. Leiden: Brill, pp. 27-43.

Duhaime, J. (1993). 'Relative Deprivation in New Religious Movements and the Qumran Community'. RevQ 16: 265-76.

Elliott, John H. (1993). What is Social-Scientific Criticism? Minneapolis, MN: Fortress Press.

Erho, Ted M. (2009). 'The Ahistorical Nature of 1 Enoch 56:5-8 and Its Ramifications upon the Opinio Communis on the Dating of the Similitudes of Enoch'. JSJ 40.1: 23-54.

Esler, Philip F. (1995). 'Introduction: Models, Context and Kerygma in New Testament Interpretation' in P. F. Esler, ed., Modelling Early Christianity: Social-Scientific Studies of the New Testament in its Context. London: Routledge, pp. 1-20.

- (2000). 'Models in New Testament Interpretation: A Reply to David Horrell'. JSNT 78: $107-13$.

- and Anselm C. Hagedorn (2006). 'Social-Scientific Analysis of the Old Testament: A Brief History and Overview' in P. F. Esler, ed., Ancient Israel: The Old Testament in Its Social Context. Minneapolis, MN: Fortress Press, pp. 15-32.

Gerhardt, Uta (2001). Idealtypus: Zur metodischen Begründung der modernen Soziologie. Frankfurt am Main, Germany: Suhrkamp.

Giddens, Anthony (1971). Capitalism and Modern Social Theory: An Analysis of the Writings of Marx, Durkheim and Max Weber. Cambridge: Cambridge University Press.

Grabbe, Lester L. (2007). 'When Is a Sect a Sect—or Not? Groups and Movements in the Second Temple Period' in D. J. Chalcraft, ed., Sectarianism in Early Judaism: Sociological Advances. London: Equinox, pp. 114-32.

Hekman, Susan J. (1983). Weber, the Ideal Type, and Contemporary Social Theory. Notre Dame, IN: University of Notre Dame Press.

Horrell, David G. (1996). The Social Ethos of the Corinthian Correspondence: Interests and Ideology from 1 Corinthians to 1 Clement. Edinburgh: T\&T Clark.

(2000). 'Models and Methods in Social-Scientific Interpretation: A Response to Philip Esler'. JSNT 78: 83-105.

Hughes, John A., Peter J. Martin, and W. W. Sharrock (1995). Understanding Classical Sociology: Marx, Weber, Durkheim. London: SAGE Publications.

Isenberg, S. R. (1974). 'Millenarianism in Greco-Roman Palestine'. Religion 4: 26-46.

Johnson, Benton (1963). 'On Church and Sect'. American Sociological Review 28: 539-49. 
Jokiranta, Jutta (2001). “'Sectarianism” of the Qumran "Sect”: Sociological Notes'. RevQ 78(20): 223-39.

-(2005). 'Identity on a Continuum: Constructing and Expressing Sectarian Social Identity in Qumran Serakhim and Pesharim'. PhD Diss. Helsinki: Helsinki University Press.

- (2006). 'The Prototypical Teacher in the Qumran Pesharim: A Social Identity Approach' in P. F. Esler, ed., Ancient Israel: The Old Testament in Its Social Context. Minneapolis, MN: Fortress Press, 254-63.

(2007). 'Social Identity in the Qumran Movement: The Case of the Penal Code' in P. Luomanen, I. Pyysiäinen, and R. Uro, eds., Explaining Christian Origins and Early Judaism: Contributions from Cognitive and Social Science. Leiden: Brill, pp. 277-98.

- (2009). 'Learning from Sectarian Responses: Windows on Qumran Sects and Emerging Christian Sects' in F. García Martínez, ed., Echoes from the Caves: Qumran and the New Testament. Studies on the Texts of the Desert of Judah. Leiden: Brill, pp. 177-210.

— and Cecilia Wassen (2009). 'A Brotherhood at Qumran? Metaphorical Familial Language in the Dead Sea Scrolls' in A. K. Petersen, T. Elgvin, C. Wassen, H. von Weissenberg, M. Winninge, and a. e. M. Ehrensvärd, eds., Northern Lights on the Dead Sea Scrolls: Proceedings of the Nordic Qumran Network 2003-2006. Leiden: Brill, pp. 173-203.

Kalberg, Stephen (2005). Max Weber: Readings and Commentary on Modernity. Malden, MA: Blackwell.

Kim, Sung Ho (2002). 'Max Weber and Civil Society: An Introduction to Max Weber on Voluntary Associational Life'. Max Weber Studies 2.2: 186-98.

Lawrence, Louise J. (2005). "Men of Perfect Holiness" (1QS 7.20): Social-Scientific Thoughts on Group Identity, Asceticism and Ethical Development in the Rule of the Community' in J. G. Campbell, W. J. Lyons, and L. K. Petersen, eds., New Directions in Qumran Studies: Proceedings of the Bristol Colloquium on the Dead Sea Scrolls, 8-10 September 2003. London: T\&T Clark International, pp. 83-100.

— and Mario I. Aguilar, eds. (2004). Anthropology and Biblical Studies: Avenues of Approach. Leiden: Deo Publishing.

Lee, David and Howard Newby (1983). The Problem of Sociology: An Introduction to the Discipline. London: Unwin Hyman.

Lim, Tiмотну H. (2002). Pesharim. Companion to the Qumran Scrolls 3. London: Sheffield Academic Press.

Ling, Tiмотнy J. (2004). 'Virtuoso Religion and the Judaean Social World' in L. J. Lawrence and M. I. Aguilar (eds.), Anthropology and Biblical Studies: Avenues of Approach. Leiden: Deo Publishing, pp. 227-58.

Lofland, John and Rodney Stark (1965). 'Becoming a World-Saver: A Theory of Conversion to a Deviant Perspective'. American Sociological Review 30: 862-75.

Luomanen, Petri, Ilkka Pyysinnen, and Risto Uro (2007). 'Introduction: Social and Cognitive Perspectives in the Study of Christian Origins and Early Judaism' in P. Luomanen, I. Pyysiäinen, and R. Uro, eds., Explaining Christian Origins and Early Judaism: Contributions from Cognitive and Social Science. Leiden: Brill, pp. 1-33.

Mayes, Andrew D. H. (1989). The Old Testament in Sociological Perspective. London: Marshall Pickering.

McGuire, Meredith B. (1997). Religion in Social Context. Belmont, CA: Wadsworth Publishing Company. 
Metso, Sarianna (1997). The Textual Development of the Qumran Community Rule. Studies on the Texts of the Desert of Judah 21. Leiden: Brill.

Murphy, Catherine M. (2002). Wealth in the Dead Sea Scrolls and in the Qumran Community. Studies on the Texts of the Desert of Judah 40. Leiden: Brill.

Newman, Hillel (2006). Proximity to Power and Jewish Sectarian Groups of the Ancient Period: A Review of Lifestyle, Values, and Halakhah in the Pharisees, Sadducees, Essenes, and Qumran. Brill Reference Library of Judaism 25. Leiden: Brill.

Newsom, Carol A. (2004). The Self as Symbolic Space: Constructing Identity and Community at Qumran. Studies on the Texts of the Desert of Judah 52. Leiden: Brill.

Niebuhr, H. Richard (1929). The Social Sources of Denominationalism. New York: Henry Holt.

Pietersen, Lloyd K. (2005). “False Teaching, Lying Tongues and Deceitful Lips” (4Q169 frgs 3-4 2.8): The Pesharim and the Sociology of Deviance' in J. G. Campbell, W. J. Lyons, and L. K. Pietersen, eds., New Directions in Qumran Studies: Proceedings of the Bristol Colloquium on the Dead Sea Scrolls, 8-10 September. London: T\&T Clark International, pp. 166-181.

Piovanelli, Pierluigi (2007). 'Was There Sectarian Behaviour before the Flourishing of Jewish Sects? A Long-Term Approach to the History and Sociology of Second Temple Sectarianism' in D. J. Chalcraft, ed., Sectarianism in Early Judaism: Sociological Advances. London: Equinox, pp. 156-79.

Rambo, Lewis Ray (1993). Understanding Religious Conversion. New Haven, CT: Yale University Press.

Regev, Eyal (2007). Sectarianism in Qumran: A Cross-Cultural Perspective. Religion and Society 45. Berlin: Walter de Gruyter.

Robbins, Vernon K. (1996). Exploring the Texture of Texts: A Guide to Socio-Rhetorical Interpretation. Valley Forge, PA: Trinity Press International.

Robertson, Ronald (1972). The Sociological Interpretation of Religion. Oxford: Basil Blackwell.

Schluchter, Wolfgang (1989). Rationalism, Religion, and Domination. Berkeley: University of California Press.

Schwartz, Shalom H. (1994). 'Are There Universal Aspects in the Structure and Contents of Human Values?' Journal of Social Issues 50.4: 19-45.

_ (2001). 'Value Hierarchies Across Cultures: Taking a Similarities Perspective'. Journal of Cross-Cultural Psychology 32.3: 268-90.

Scott, John and Gordon Marshall (2005). Oxford Dictionary of Sociology. 3rd edn. Oxford: Oxford University Press.

Sivertsev, Alexei M. (2005). Households, Sects, and the Origins of Rabbinic Judaism. Supplements to the Journal for the Study of Judaism 102. Leiden/Boston: Brill.

Stark, Rodney (1999). 'Micro Foundations of Religion: A Revised Theory'. Sociological Theory: A Journal of the American Sociological Association 17.3: 264-89.

—and William Sims Bainbridge (1985). The Future of Religion: Secularization, Revival and Cult Formation. Berkeley: University of California Press. (1987). A Theory of Religion. New York: Peter Lang.

Talmon, Shemaryahu (1987). 'The Emergence of Jewish Sectarianism in the Early Second Temple Period' in P. D. Miller Jr., P. D. Hanson, and S. D. McBride, eds., Ancient Israelite Religion: Essays in Honor of Frank Moore Cross. Philadelphia, PA: Fortress Press, 587-616. 
Troeltsch, Ernst (1981). The Social Teaching of the Christian Churches, with an introduction by H. Richard Niebuhr. Trans. Olive Wyon. Chicago: University of Chicago Press.

(1991). Religion in History. Essays translated by James Luther Adams and Walter F. Bense with an introduction by James Luther Adams. Minneapolis, MN: Fortress Press.

Wallis, Roy 1975. 'The Cult and Its Transformation' in R. Wallis, ed., Sectarianism: Analyses of Religious and Non-Religious Sects. London: Peter Owen, pp. 35-49.

Wassen, Cecilia and Jutta Jokiranta (2007). 'Groups in Tension: Sectarianism in the Damascus Document and the Community Rule' in D. J. Chalcraft, ed., Sectarianism in Early Judaism: Sociological Advances. London: Equinox, pp. 205-45.

Weber, Max (1949). The Methodology of the Social Sciences. Trans. Edward Shils and Henry Finch. New York: The Free Press.

(1952). Ancient Judaism. Trans. Hans H. Gerth and Don Martindale. New York: The Free Press.

- (2002a). The Protestant Ethic and the Spirit of Capitalism. New introduction and translation by Stephen Kalberg. London: Blackwell.

(2002b). 'Voluntary Associational Life (Vereinswesen).' Trans. Sung Ho Kim. Max Weber Studies 2.2: 199-209.

Wilson, Bryan R. (1967). 'An Analysis of Sect Development' in B. R. Wilson, ed., Patterns of Sectarianism: Organization and Ideology in Social and Religious Movements. London: Heinemann, pp. 22-45.

- (1970). Religious sects: A Sociological Study. London: World University Library.

- (1973). Magic and the Millennium: A Sociological Study of Religious Movements of Protest among Tribal and Third-World Peoples. London: Heinemann.

- (1982). Religion in Sociological Perspective. Oxford: Oxford University Press.

- (1990). The Social Dimension of Sectarianism: Sects and New Religious Movements in Contemporary Society. Oxford: Clarendon Press. 